\title{
DA PERSPECTIVA DO RETORNO À CONSOLIDAÇÃO DO CAMINHO SEM VOLTA
}

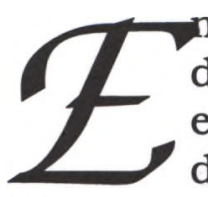

m seu número 21, ( janeiro-abril/95), Travessia divulgava os resultados dos primeiros estudos referentes aos brasileiros no exterior, fato novo e recente de nossa história, irrompido a partir de meados da década de 1980. Seu volume, visto daqui, surpreendia, porém, a partir da ótica do destino, tratava-se ainda de uma "minoria invisivel", para a qual, no horizonte da maioria, delineava-se o retorno.

Transcorrida mais uma década, revisitamos o tema. Em termos quantitativos, o fluxo só fez aumentar, já se fala num êxodo de 3 milhões, mas a preocupação, aqui, vai noutra direção. À medida que o túnel do tempo avança, vivenciam concretamente o esmaecimento da perspectiva da volta, contudo, o eterno mito do retorno continua persistindo entre os sujeitos do processo. Um sentimento ambíguo é o que define o atual estágio de muitos: “Eu bem que poderia não estar aqui”, declarou com os olhos cheios d'água uma entrevistada nos Estados Unidos, após desfilar um rosário de reclamações e insultos contra o Brasil. Por isso, o olhar dos articulistas recai sobre a permanência.

Quer no Japão, quanto nos Estados Unidos, já há uma rede constituída de serviços e negócios para, e especialmente, de brasileiros, sinalizando a consolidação de um caminho sem volta. Muito gaman (resistência), é o que resta aos que rumaram na direção do sol nascente, pois o que surgiu como eminentemente temporário já ganhou o selo da permanência. Nos Estados Unidos já há iniciativas de organização em prol e dos próprios migrantes. Insipientes ainda, é verdade, mas já balbuciam algo de novo - um tom militante.

Em se tratando, porém, de fluxo relativamente recente, para além das redes constituídas, canais por onde flui a própria migração e sua inserção no mercado de trabalho, transparece com força o papel desempenhado pelas igrejas no local de destino. Trata-se de um locus privilegiado que atua como mediação entre o que ficou para trás e a realidade de um outro cotidiano. Mediação que se efetiva não ipso facto, mas à medida que o migrante pode aí saciar as suas muitas e variadas demandas. Disso advém a importância da Pastoral dos Brasileiros no Exterior, de responsabilidade da Conferência Nacional dos Bispos do Brasil, em curso desde 1996.

Mas não é só o lado de lá, onde os migrantes fixam nova residência, o que chama agora a atenção. Cada vez mais, a própria fronteira, no caso do México com os Estados Unidos, está transformando o binômio prisão-deportação em experiência constitutiva do ato de migrar - quer por parte de brasileiros, quer por parte de muitos, muitos outros.

Dircen Cuttr 